\title{
Alumni Satisfaction Analysis with UnivQual Theory: Case of Telkom University Class of 2010-2014
}

\author{
Mahir Pradana* \\ Telkom University, Indonesia \\ Benny Kurnia \\ Telkom University, Indonesia \\ Tri Indra Wijaksana \\ Telkom University, Indonesia \\ Fajar Ari Rachdian \\ Telkom University, Indonesia \\ Diki Wahyu Nugraha \\ Politeknik Pos, Indonesia \\ * mahirpradana@telkomuniversity.ac.id
}

\begin{abstract}
This research was conducted to determine the crucial attributes used by students in choosing universities to enter, in this case choosing to enroll at Telkom University, where the object of this research is the Business Administration students class 2010-2014. The purpose of this study is to explore the factors that are considered by prospective students in making decisions to choose Telkom University campus for study and to find out the dominant factors in choosing the Telkom University campus as a place to study. This research uses a quantitative approach. The scale of the instrument used in this study was the Likert scale. The population in this study were alumni of Telkom University. Tel-U has 45,743 alumni who are members of the Telkom University Alumni Forum (FAST). This study uses a non-probability sampling technique with a purposive sampling type. The data analysis technique used descriptive analysis. It can be concluded that there is no significant effect of the curriculum on improving Telkom University students' skills. We also found a significant effect of facilities and services on improving the skills of Telkom University students. Last we found a significant effect of skill development on Telkom University students' satisfaction.
\end{abstract}

\section{Keywords: UnivQual; Education Management; Business Administration}

\section{Introduction}

Education has a significant role in life, especially if supervised by efforts to improve human resources quality (HR). To get that human resource quality, a place for human resources plays an important role, such as the level of education in university (Pradana, 2016). One of the university's goals is competitive advantage through resource management in terms of professional human resources. This fact shows that being competitive is a new challenge for universities. In this case, leadership and management are the main factors universities have become more responsive to consumer needs or demands. College or university has various departments and different facilities. Therefore, prospective students will not carelessly in choosing the college to be occupied.

For example, in Asia, according to Lee and Chatfield (2015) in their research, in the selection of universities in the field of tourism and hospitality, many considerations and factors 
influence it. This case identified the factors which influence student choices, including domestic students, overseas students, and international students (Fakhri et al., 2017). The results showed that international students consider costs, facilities, family support. Impressive results also come from media such as television (TV) programs, social media, and significant news that can affect prospective students in choosing a university. Decision making by prospective students is how they can identify the education by which they are regulated.

Suppose the theory is a decision-making model, where the stages in making the decision start from recognizing needs, whether education is one of the personal needs or not. The consumer will then look for information that needs to be stored in memory (internal search) and obtain information relevant to decisions from the environment (external search).

In this case, consumers or prospective students are looking for information about Telkom University (Pradana \& Puspitasari, 2016). The next step is the evaluation of alternatives, where some basic concepts will help understand the consumer evaluation process: Consumers try to meet a need, look for specific benefits from the product solution, and see each product as a collection of attributes with different abilities in providing satisfaction benefits.

After making the decision, it will be seen how consumer behavior tends to be after choosing Telkom University. The success of a business is responsive very much to the company's existing marketing strategy. One of the instruments used to develop a marketing strategy is to use the factor analysis method decision making from several experts, namely Marimon et al. (2019). Therefore, we aim this research to see the essential attributes used by students in choosing universities to enter, in choosing this registering at Telkom University, where the object of this research is Business Administration students batch 2010-2014.

\section{Literature Review and Hypotheses}

According to Kotler and Keller (2016) the definition of service is as follows: "Service is any action or performance that one party can offer to another who is essentially intangible and does not result in any ownership. Service itself has characteristics, namely:

- Strongly influenced by emotionally driven motives.

- Services are intangible, different from goods that are tangible, can be seen, tasted, smelled, etc.

- Durable goods, but not service. Service is purchased and consumed at the same time.

- Goods can be stored, while services cannot be stored.

- Estimating demand in the marketing of goods is a problem, as is marketing services.

- Service business pays great attention to the human element.

- Direct distribution from producers to consumers.

According to Ladhari (2009), one of the most popular methods is used to measure quality service is the SERVQUAL model. According to Parasuraman, Berry, \& Zeithaml (1993), SERVQUAL operationalize service quality by comparing the perceptions of service received with hope. Since this method was published, a number of variations have developed. In the special context of Higher Education, Brown and Mazzarol (2009) adapted the SERVQUAL method and found that one of the most important of the perceived value is the image of the institution, while the perceived quality of the people and physical processes, 
infrastructure and services have weak and unclear impacts. Furthermore, a series of studies examining how universities perform using the SERVQUAL method and compare results with other methods.

Marimon et al. (2019) have findings that reveal students are important, and that the three categories included in the UnivQual method can provide meaningful information for university managers. If processed properly, the data collected can very useful for making more informed decisions. Not all universities will focus on efforts and their resources in the same direction. Universities need to evaluate themselves first, look at their weaknesses and strengths and then outline a strategic plan to determine their future actions. Marimon et al. (2019) have designed and validated the method of UnivQual, to assess students' perceptions holistically about the quality of services provided at the university. This method presents its hallmark as a useful instrument not only for assessing the subject.

Alternatively, individually, but also to capture students' perceptions of students after completing their studies. Therefore, it contains a number of items that refer to the entire academic program. This study proposed the UnivQual method to evaluate students' perceptions of service quality by considering the academic component of the service experience and its factors as part of the service package as an implicit feature (eg public services, facilities and equipment). The following is the research framework in this study.

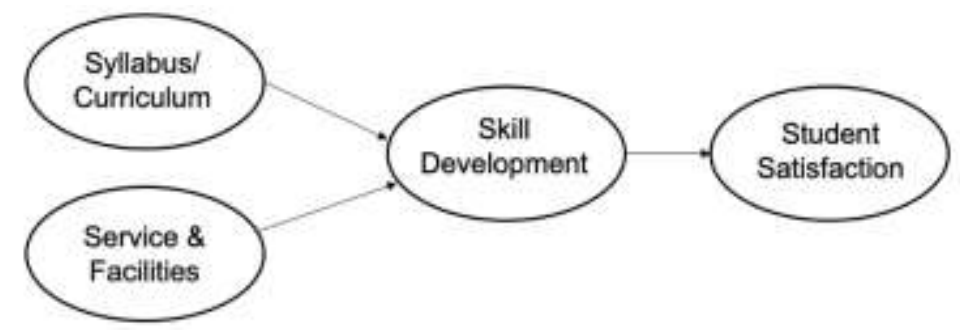

Figure 1. Research Framework

\section{Research Methodology}

This study uses a quantitative approach. The processing results are then presented in numeric form so that it makes it easy for anyone who needs information regarding the research. According to Augustriati et al. (2017), the quantitative method basically includes determining the subject to be requested information or data, the techniques used in data collection, and the treatment to be selected. Quantitative methods also generally want to know the relationship between two or more variables previously described in accordance with the theory on which the Operational Variable and Measurement Scale is based.

The population in this study were alumni of Telkom University. The university has a number of alumni who are members of the Telkom University Alumni Forum (FAST) as of August 2019 amounting to 45,743 people. According to Indrawati (2015) the sample is members of the population who are elected to be involved in research, either to be observed, given treatment, or asked for their opinion about what is being researched. After calculating the population with Slovin formula, we decided to distribute the questionnaire to 100 alumni with purposive sampling method.

Therefore, our study uses a non-probability sampling technique with a purposive sampling type. Non-probability sampling is a sampling technique that does not provide opportunities or opportunities for each element or member of the population to be selected as a sample (Sugiyono, 2017). Meanwhile, purposive sampling, namely selecting members of a particular sample deliberately by the researcher, because the sample is only who represent or 
can provide information to answer research problems (Indrawati, 2015). The sample of this research is 100 Telkom University alumni or former students class 2010-2014. Hypoteses for this research are:

Hypothesis 1: The curriculum has a positive effect on student skill development Hypothesis 2: Services \& facilities have a positive effect on skill development Hypothesis 3: Student skill development has a positive effect on student satisfaction

\section{Discussion}

This study aims to examine the effect of curriculum, facilities \& services, skills improvement and student satisfaction at Telkom University 2010-2014. The data is processed using structural equation modeling with the alternative method of partial least square. In structural equation modeling, there are two types of models that are formed, namely measurement models and structural models. The measurement model describes the proportion of the variance of each manifest variable (indicator) that can be explained in the latent variable. After the measurement model for each latent variable is described, a structural model will be described which will examine the effect of each independent latent variable (exogenous latent variable) on the endogenous latent variable.

The measurement model is a model that connects latent variables with the manifest variable. In this study, there are 4 latent variables measured by 20 indicators. Through the loading factor it can be seen the validity of each indicator and test the reliability of the constructs of the variables under study (Fornell \& Larcker, 1981). The indicator is said to be valid if it has a factor weight greater than 0.70 . From the picture, it can be seen that all items have a loading factor above 0.70 so that all items are valid. For more details, see the following table:

Table 1. Item Validity

\begin{tabular}{|c|c|r|c|}
\hline \multirow{7}{*}{ Variables } & Indicators & \multicolumn{1}{c|}{$\begin{array}{c}\text { Loading } \\
\text { factors }\end{array}$} & Verdict \\
\hline \multirow{7}{*}{ Curriculum } & K1 & $\mathbf{0 , 7 9 6}$ & Valid \\
\cline { 2 - 4 } & K2 & $\mathbf{0 , 8 0 7}$ & Valid \\
\cline { 2 - 4 } & K3 & $\mathbf{0 , 7 6 8}$ & Valid \\
\cline { 2 - 4 } & K4 & $\mathbf{0 , 7 7 3}$ & Valid \\
\cline { 2 - 4 } & K5 & $\mathbf{0 , 8 2 3}$ & Valid \\
\cline { 2 - 4 } & K6 & $\mathbf{0 , 7 6 2}$ & Valid \\
\cline { 2 - 4 } & K7 & $\mathbf{0 , 7 9 8}$ & Valid \\
\hline \multirow{5}{*}{ Facility \& Service } & FP1 & $\mathbf{0 , 7 9 1}$ & Valid \\
\cline { 2 - 4 } & FP2 & $\mathbf{0 , 8 0 0}$ & Valid \\
\cline { 2 - 4 } & FP3 & $\mathbf{0 , 8 1 5}$ & Valid \\
\hline
\end{tabular}


INOBIS: Jurnal Inovasi Bisnis dan Manajemen Indonesia

Volume 03, Nomor 02, Maret 2020

Mahir Pradana, Benny Kurnia, Tri Indra Wijaksana, Fajar Ari Rachdian, Diki Wahyu Nugraha

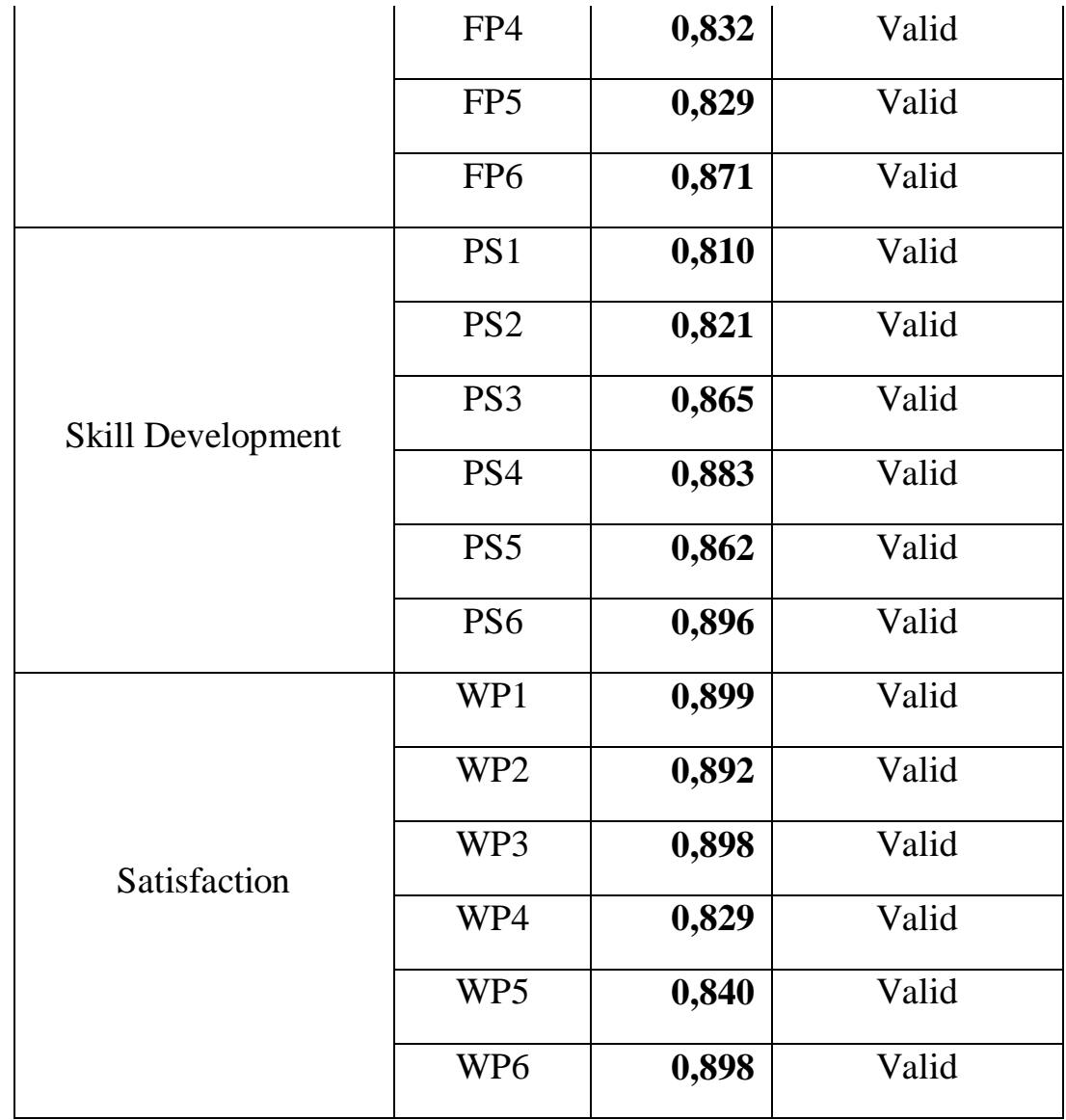

Source: Authors' own elaboration (2020)

The following table 2 is the result of the convergent validity test which includes the loading factor, AVE value and CR value for each research variable.

Table 2. Reliability

\begin{tabular}{|c|c|c|c|c|c|}
\hline Variables & Indicators & $\begin{array}{l}\text { Loading } \\
\text { factors }\end{array}$ & AVE & CR & Verdict \\
\hline \multirow{7}{*}{ Curriculum } & K1 & 0,796 & \multirow{7}{*}{0,624} & \multirow{7}{*}{0,927} & \multirow{7}{*}{ Reliable } \\
\hline & $\mathrm{K} 2$ & $\mathbf{0 , 8 0 7}$ & & & \\
\hline & K3 & 0,768 & & & \\
\hline & K4 & 0,773 & & & \\
\hline & K5 & 0,823 & & & \\
\hline & K6 & 0,762 & & & \\
\hline & K7 & 0,798 & & & \\
\hline
\end{tabular}


INOBIS: Jurnal Inovasi Bisnis dan Manajemen Indonesia

Volume 03, Nomor 02, Maret 2020

Mahir Pradana, Benny Kurnia, Tri Indra Wijaksana, Fajar Ari Rachdian, Diki Wahyu Nugraha

\begin{tabular}{|c|c|c|c|c|c|}
\hline \multirow{6}{*}{$\begin{array}{l}\text { Facility \& } \\
\text { Service }\end{array}$} & FP1 & 0,791 & \multirow{6}{*}{0,678} & \multirow{6}{*}{0,921} & \multirow{6}{*}{ Reliable } \\
\hline & FP2 & 0,800 & & & \\
\hline & FP3 & 0,815 & & & \\
\hline & FP4 & 0,832 & & & \\
\hline & FP5 & 0,829 & & & \\
\hline & FP6 & 0,871 & & & \\
\hline \multirow{6}{*}{$\begin{array}{c}\text { Skill } \\
\text { Development }\end{array}$} & PS1 & 0,810 & \multirow{6}{*}{0,734} & \multirow{6}{*}{0,943} & \multirow{6}{*}{ Reliable } \\
\hline & PS2 & 0,821 & & & \\
\hline & PS3 & 0,865 & & & \\
\hline & PS4 & $\mathbf{0 , 8 8 3}$ & & & \\
\hline & PS5 & 0,862 & & & \\
\hline & PS6 & 0,896 & & & \\
\hline \multirow{6}{*}{ Satisfaction } & WP1 & 0,899 & \multirow{6}{*}{0,768} & \multirow{6}{*}{0,952} & \multirow{6}{*}{ Reliable } \\
\hline & WP2 & 0,892 & & & \\
\hline & WP3 & 0,898 & & & \\
\hline & WP4 & 0,829 & & & \\
\hline & WP5 & 0,840 & & & \\
\hline & WP6 & 0,898 & & & \\
\hline
\end{tabular}

Source: Authors' own elaboration (2020)

Based on the processing results presented in the table above, it can be seen that all latent variables have AVE values above 0.5 and $C R$ above 0.7 so that they are declared reliable.

The following table 3 is a summary of the results of the structural model statistical test to answer the research hypothesis: 
Table 3. Path Coefficients

\begin{tabular}{|c|l|c|c|c|c|}
\hline Hypothesis & Relationship & Path Coefficient & p-value & T-stat & Verdict \\
\hline H1 & $\begin{array}{l}\text { Curriculum } \\
\text { has positive } \\
\text { effect on skill } \\
\text { development }\end{array}$ & 0,268 & 0,109 & 1,604 & $\begin{array}{c}\text { Valid but not } \\
\text { significant }\end{array}$ \\
\hline $\mathbf{H 2}$ & $\begin{array}{l}\text { Curriculum } \\
\text { has positive } \\
\text { effect on skill } \\
\text { development }\end{array}$ & 0,837 & 0,000 & 20,136 & $\begin{array}{c}\text { Valid and } \\
\text { significant }\end{array}$ \\
\hline $\mathbf{H 3}$ & $\begin{array}{l}\text { Skill } \\
\text { development } \\
\text { has positive } \\
\text { effect on } \\
\text { satisfaction }\end{array}$ & 0,862 & 0,000 & 20,451 & $\begin{array}{c}\text { Valid and } \\
\text { significant }\end{array}$ \\
\hline
\end{tabular}

Source: Authors' own elaboration (2020)

We then continue to the testing of the hypothesis If $\mathrm{F}$ count $<\mathrm{F}$ table then $\mathrm{H} 0$ is in the acceptance area, it means that H1 is rejected or there is no significant effect. The following describes each hypothesis testing

a. Hypothesis 1

Hypothesis:

H0: There is no significant effect of the curriculum on skill improvement.

H1: There is a significant influence by the curriculum on skill improvement.

Based on the provisions previously stated, where the t-count is 1.604 and at the $5 \%$ (2 tailed) significance level, the t-table is 1.96 , so that the $t$-count (1.604) <t-table (1.96). This means that $\mathrm{H} 0$ is accepted and $\mathrm{H} 1$ is rejected, so there is no significant effect of the curriculum on skill improvement.

Judging from the path coefficient of 0.268 . The path coefficient is positive, meaning that there is a direct relationship between the curriculum variables and skill improvement. These results indicate that if the curriculum variable value is higher, then the value of increasing skills will decrease, and not at a significant level.

b. Hypothesis 2

Hypothesis:

H0: There is no significant effect of facilities and services on skill improvement H1: There is a significant effect of facilities and services on skill improvement 
Based on the provisions previously stated, where the $\mathrm{t}$-count is 20.136 and at the $5 \%$ (2 tailed) significance level, the t-table is 1.96 , so that $t$-count (20.136) $>t$-table (1.96). This means that $\mathrm{H} 0$ is rejected and $\mathrm{H} 2$ is accepted, so there is a significant effect of facilities and services on skill improvement.

Judging from the path coefficient of 0.837 . The path coefficient is positive, meaning that there is a unidirectional relationship between the Facility and Service variables on skill improvement. This result shows that if the Facility and Service variables increase, it will increase the skill increase, and vice versa.

c. Hypothesis 3

Hypothesis:

H0: There is no significant effect of Skill Improvement on satisfaction.

H1: There is a significant effect of Skill Improvement on satisfaction.

Based on the provisions previously stated, where the $t$-count is 20.451 and at the $5 \%$ (2 tailed) significance level, the $t$ table is 1.96 , so that the $t$-count (20.451) $>t$-table (1.96). This means that $\mathrm{H} 0$ is rejected and $\mathrm{H} 3$ is accepted, so there is a significant effect of Skill Improvement on satisfaction.

Judging from the path coefficient of 0.862 . The path coefficient is positive, meaning that there is a direct relationship between the Skill Increase variable and satisfaction. These results indicate that if the Skill Improvement variable increases, it will increase student satisfaction.

\section{Conclusion}

Based on research conducted regarding the satisfaction of choosing Telkom University with the univqual theory of the 2010-2014 alumni, the following conclusions can be drawn:

- The syllabus variable is in the high category with a total score of $83.4 \%$. This means that the syllabus or learning curriculum owned by Telkom University is good.

- Facility \& service variables are in the high category with a total score of $69.4 \%$. This means that the facilities and services owned by Telkom University are good.

- The variable of skill improvement is in the high category with a total score of $80.4 \%$. This means that the skill improvement of Telkom University students is good.

- The satisfaction variable is in the high category with a total score of $76.8 \%$. This means that Telkom University student satisfaction is good.

- Based on testing the hypothesis 1 , it can be concluded that there is no significant effect of the curriculum on improving the skills of Telkom University students.

- Based on testing the hypothesis 2, it can be concluded that there is a significant effect of facilities and services on improving the skills of Telkom University students. 
Mahir Pradana, Benny Kurnia, Tri Indra Wijaksana, Fajar Ari Rachdian, Diki Wahyu Nugraha

- Based on testing the hypothesis 3, it can be concluded that there is a significant effect of Skill Improvement on Telkom University student satisfaction.

Based on the results of data analysis on research on the satisfaction of choosing Telkom University with the UnivQual theory of the 2010-2014 alumni, the following suggestions can be made:

- The facility \& service variable that has the lowest score is the statement "Online platform (virtual campus) is a suitable environment to generate knowledge and improve my learning". Therefore, researchers suggest that the online platform at Telkom University be improved so that it can improve student learning.

- The satisfaction variable which has the lowest score is the statement "I am satisfied because I always do the assigned task well". Therefore, researchers provide suggestions so that teachers can provide assignments that not only improve the learning process, but can also attract students' interest in new things which of course still relate to the material provided.

We also offer suggestions for further researchers to be put forward as follows:

- The variables used in this research are curriculum, facilities \& services, skills improvement and satisfaction variables. It is recommended for further researchers to examine other factors that affect student satisfaction at Telkom University, for example: school culture, joob opportunities. This suggestion is proposed in order to obtain varied results.

- Further suggestions related to the object of research, the next researcher should use a different scope. So that further research is expected to expand the object of research or conduct research at other companies.

\section{References}

Augustrianto, A., Silvianita, A., Ferari, E. (2019) Hofstede's organization culture on deviant workplace behavior (Case study on workers at plaza Toyota Bandung). Journal of Advanced Research in Dynamical and Control Systems, 11(3 Special Issue), pp.720725

Brown, R. M., \& Mazzarol, T. W. (2009). The importance of institutional image to student satisfaction and loyalty within higher education. Higher education, 58(1), 81-95.

Fakhri, M., Pradana, M., Virgintia, E., \& Gilang, A. (2017, August). Determinants of Competence in Supporting Student's Career Goals. In 8th International Conference of Asian Association of Indigenous and Cultural Psychology (ICAAIP 2017). Atlantis Press.

Fornell, C., \& Larcker, D. F. (1981). Evaluating structural equation models with unobservable variables and measurement error. Journal of Marketing Research, 18(1), 39-50.

Indrawati, I., \& Indriasari, D. (2015). Pemanfaatan Big Data Analysis Dalam Meningkatkan Loyalitas Pelanggan High Speed Internet (studi Kasus Telkom Divisi Regional Ii Jakarta). eProceedings of Management, 2(2).

Kotler, P. (2016). A framework for marketing management. Pearson Education Limited.

Lee, H. J., Chatfield, R. B., \& Strawa, A. W. (2016). Enhancing the applicability of satellite remote sensing for PM2. 5 estimation using MODIS deep blue AOD and land use 
regression in California, United States. Environmental Science \& Technology, 50(12), 6546-6555.

Marimon, F., Mas-Machuca, M., Berbegal-Mirabent, J., \& Llach, J. (2019). UnivQual: a holistic scale to assess student perceptions of service quality at universities. Total Quality Management \& Business Excellence, 30(1-2), 184-200.

Parasuraman, A., Berry, L. L., \& Zeithaml, V. A. (1993). More on improving service quality measurement. Journal of retailing, 69(1), 140-147.

Pradana, M. (2016). Perencanaan Skema Sistem Informasi Untuk Aktivitas Manajemen. EKOMBIS REVIEW: Jurnal Ilmiah Ekonomi dan Bisnis, 4(1).

Pradana, M., \& Puspitasari, D. N. (2016). Webqual Analysis Of Telkom University's Openlibrary System From The Perspectives Of Communication And Business Students. Bandung Creative Movement (BCM) Journal, 3(1).

Saragih, R., Fakhri, M., Pradana, M., Gilang, A., \& Vidjashesa, G. A. (2018). Ethical Leadership's Effect on Employee Discipline: Case of An Indonesian Telecommunication Company. In Proceedings of the International Conference on Industrial Engineering and Operations Management.

Sugiyono. (2017). Metode Penelitian Kuantitatif, Kualitatif, dan R\&D. Alfabeta. 